\title{
SAND ACCUMULATION IN WAVE-SHELTER ZONE OF OHARAI PORT AND CHANGE IN GRAIN SIZE OF SEABED MATERIALS ON NEARBY COAST
}

\author{
Takeo Matsu-ura ${ }^{1}$, Takaaki Uda ${ }^{2}$, Takayuki Kumada ${ }^{2}$ and Michio Sumiya ${ }^{2}$ \\ Beach changes around Oharai Port facing the Pacific Ocean were investigated using bathymetric survey data \\ collected over 25 years between 1979 and 2004. Between the south and offshore breakwaters of Oharai Port, $1.50 \times$ \\ $10^{6} \mathrm{~m}^{3}$ of fine sand was deposited in this period, i.e., at an annual rate of $6.0 \times 10^{4} \mathrm{~m}^{3} / \mathrm{yr}$, which was originally \\ supplied from the Naka River $3 \mathrm{~km}$ north of the port. Also in the wave-shelter zone of the offshore breakwater south \\ of the port, $7.0 \times 10^{6} \mathrm{~m}^{3}$ of fine sand was deposited between 1979 and 2004 at an annual rate of $2.8 \times 10^{5} \mathrm{~m}^{3} / \mathrm{yr}$, \\ which was transported by the northward longshore sand transport induced from outside to inside the wave-shelter \\ zone of the offshore breakwater, resulting in severe beach erosion on the south coast outside the wave-shelter zone. \\ Taking into consideration the fact that sand transport to the Kashimanada coast is now completely obstructed by the \\ port breakwaters, sand bypassing and sand back passing to the coast from the sand deposition zone of Oharai Port are \\ required.
}

Keywords: sand bypassing; sand back passing; sand deposition in the navigation channel; longshore sand transport; sediment supply from river

\section{INTRODUCTION}

The construction of a large-scale breakwater often causes beach erosion on the nearby coast because it induces strong longshore sand transport from outside to inside the wave-shelter zone. Although various measures have been taken to prevent beach erosion, there are many examples of such beach changes in Japan (Uda, 2009). One such example is the beach changes around Oharai Port located at the north end of the 97-km-long Kashimanada coast, which faces the Pacific Ocean. The construction of a 1297-m-long offshore breakwater at this port began in 1979, forming a wide waveshelter zone in the lee of the offshore breakwater and inducing longshore sand transport toward the wave-shelter zone and severe beach erosion on the nearby coast. The sequential beach changes around this port have been used to enhance the accuracy of predictive models of beach changes. Mimura and Kato (1991) studied beach changes up to 1990, and Kumada et al. (2007) investigated the change in sand volume in the accretion zone. In these studies, however, the changes in longitudinal profiles and in the grain size of seabed materials were not studied. Also a quantitative analysis of sand supply from the Naka River, the source of sand to the coast, was not made. Here, beach changes around Oharai Port and longshore sand transport toward the wave-shelter zone were investigated in detail on the basis of field data. Then, the possibility of sand bypassing, in which sand deposited in the port is transported to the Kashimanada coast, was studied as a measure for preventing sand deposition in the navigation channel of Oharai Port and preventing the erosion on the Kashimanada coast.

\section{GENERAL CONDITIONS OF STUDY COAST}

The main sources of sand to the Kashimanada coast are the Naka River, $3 \mathrm{~km}$ north of Oharai Port, and the Tone River, which flows into the Kashimanada coast at the south end of the coast (Fig. 1). A sandy beach has been formed by fluvial sand supplied from these rivers. Kashima Port, however, was constructed midway along the coast and a breakwater at the port was extended to a point depth of $24 \mathrm{~m}$, which is much deeper than the depth of closure of approximately $9 \mathrm{~m}$ on this coast. Since then, sand supplied from the Tone River has not been able to reach the coast north of Kashima Port. On the other hand, at the north end of the coast, where Oharai Port is located, a large wave-shelter zone was formed as a result of the construction of the south and offshore breakwaters, making it difficult for longshore sand to be transported smoothly across the port. Thus, the sand supply to the coast under study is entirely obstructed by port breakwaters at present. Beach changes on this coast are superimposed on this long-term change owing to the lack of sand supply, and beach erosion has become severe along the entire coast.

\footnotetext{
${ }^{1}$ Takahagi Public Works Office, Ibaraki Prefectural Government, 1405-2 Shimotezuna, Takahagi, Ibaraki 318-0003, Japan

2 Public Works Research Center, 1-6-4 Taito, Taito, Tokyo 110-0016, Japan
} 


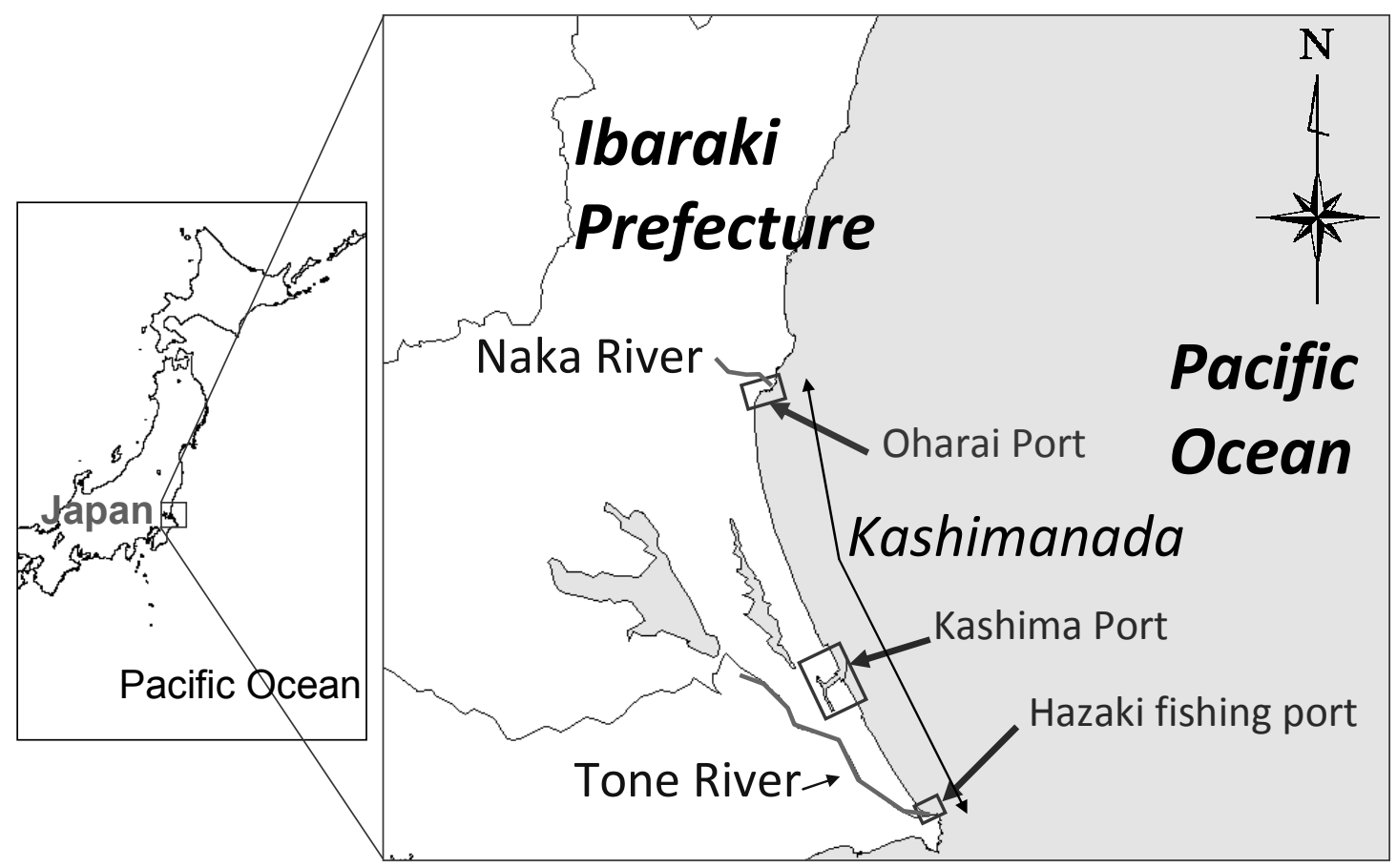

Figure 1. Location of Kashimanada coast and Oharai Port.

Figures 2(a) and 2(b) show aerial photographs of Oharai Port taken in 1964 under natural conditions and in 2006 after the construction of Oharai Port. In 1964 a natural sandy beach with a $50 \mathrm{~m}$ width extended alongshore at the north end of the coast, where Oharai Port breakwater was later constructed, and sand supplied from the Naka River was able to be transported southward. In 2006, an offshore breakwater of $900 \mathrm{~m}$ length extended directly in the south-north direction with an oblique part of $300 \mathrm{~m}$ length at its south end. Because the predominant wave direction of this coast is from the east (Kumada et al., 2007), a wide wave-shelter zone was formed in the lee of the offshore breakwater, and northward longshore sand transport toward inside the wave-shelter zone was induced, resulting in sand accumulation in the wave-shelter zone. The shoreline position along the west jetty had advanced up to $750 \mathrm{~m}$ by 2006 compared with its position in 1964 and, in contrast, the shoreline retreated on the southern coast, resulting in the exposure of the seawall to waves.

(a) 1964

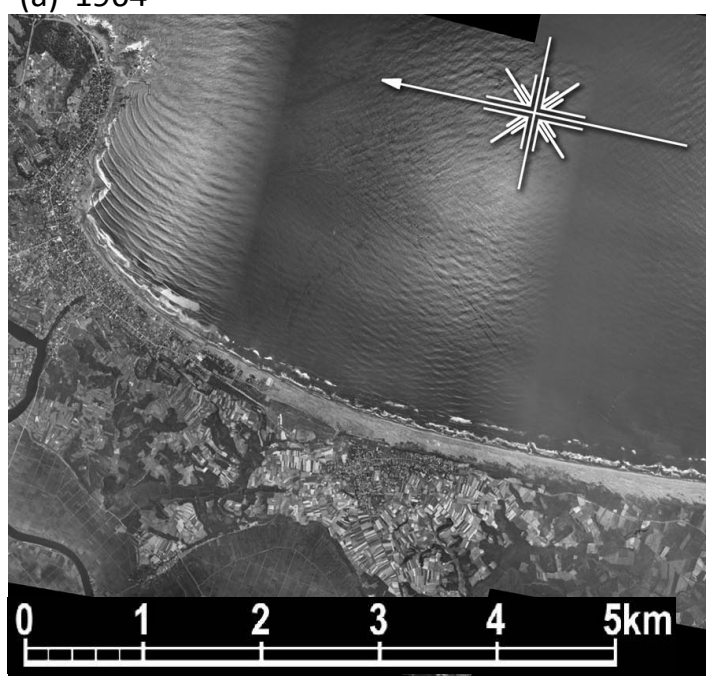

(b) 2006

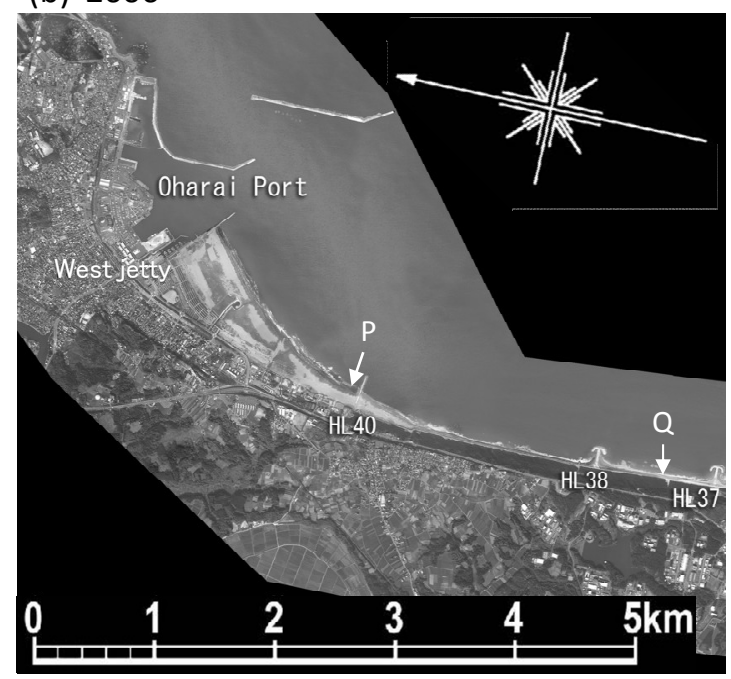

Figure 2. Aerial photographs around Oharai Port taken in (a)1964 and (b)2006. 
For example, Fig. 3 shows a photograph of the shoreline taken on October 1, 2008 looking north from point $\mathrm{P}$ shown in Fig. 2(b) inside the wave-shelter zone of Oharai Port. It can be observed that fine sand has been deposited forming a very gentle slope. In contrast, the coastline is barely protected by the seawall and a large number of concrete blocks in the erosion zone, as shown in Fig. 4, a photograph taken on the same day at point Q $4.5 \mathrm{~km}$ south of Oharai Port. The foreshore of this coast has completely eroded and has disappeared, resulting in frequent damage due to wave overtopping and the subsidence of concrete blocks. The impounding of the land by the seawall further led to the deepening of the depth in front of the seawall (Uda, 2009).

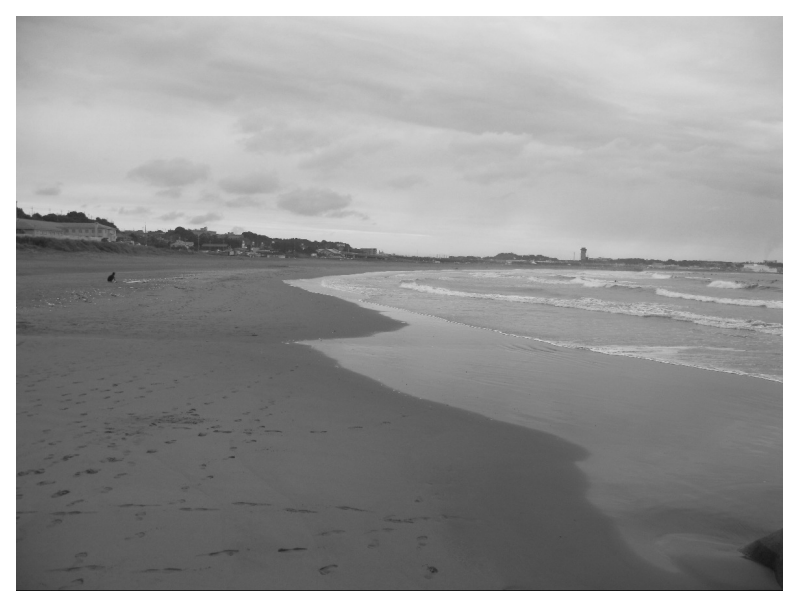

Figure 3. Photograph of gentle slope formed by deposition of fine sand in wave-shelter zone taken from point $P$ in Fig. 2.

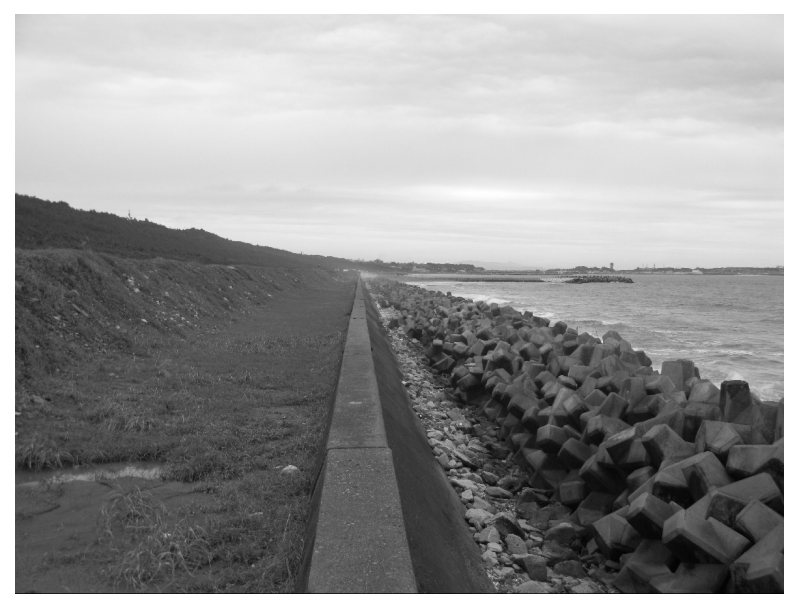

Figure 4. Photograph of seawall and concrete blocks exposed to waves taken at point $Q$ in Fig. 2.

\section{ACQUISITION OF FIELD DATA}

A bathymetric survey has been carried out once a year since 1979 at $200 \mathrm{~m}$ intervals alongshore around Oharai Port. In this study, the bathymetric changes until 1980, 1990, 2000 and 2004 with reference to the bathymetry in 1979 are compared as typical cases. For example, Fig. 5 shows the bathymetry in 1980 and the alignment of transects used in the study. On the basis of the survey data, volume changes around the port since 1979 were also calculated and the changes in longitudinal profiles between 1979 and 2004 along four transects (A, B, C and D) were investigated. The sampling of seabed materials was also carried out along transects in the accretion and erosion zones, respectively, and the depth distribution of $\mathrm{d}_{50}$ along each transect was obtained. Transects $\mathrm{A}$ and $\mathrm{B}$ were set in the sand accretion zone, whereas transects $\mathrm{C}$ and $\mathrm{D}$ were set in the erosion zone south of the port, as shown in Fig. 5. 


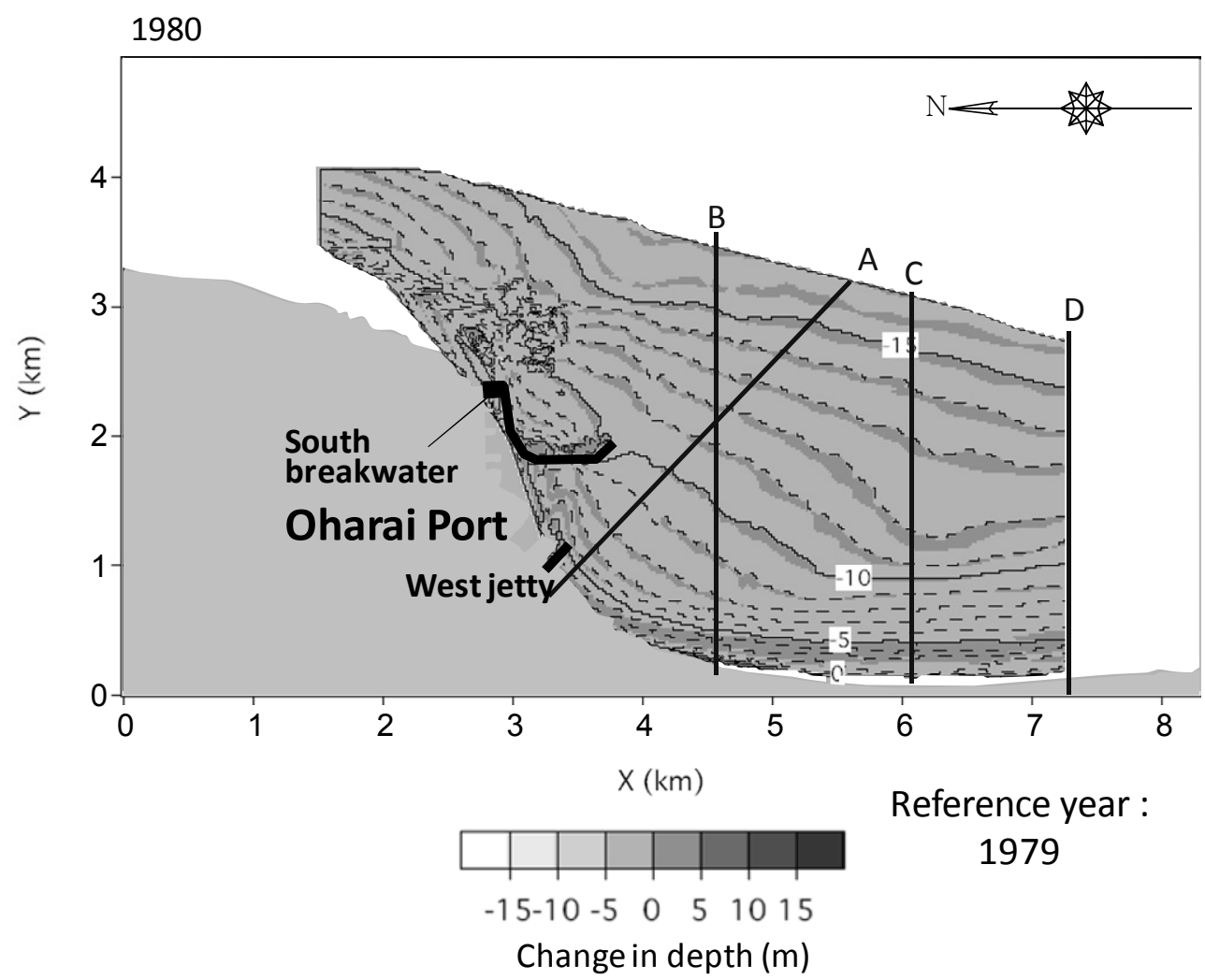

Figure 5. Bathymetric changes between 1979 and 1980 and alignment of transects.

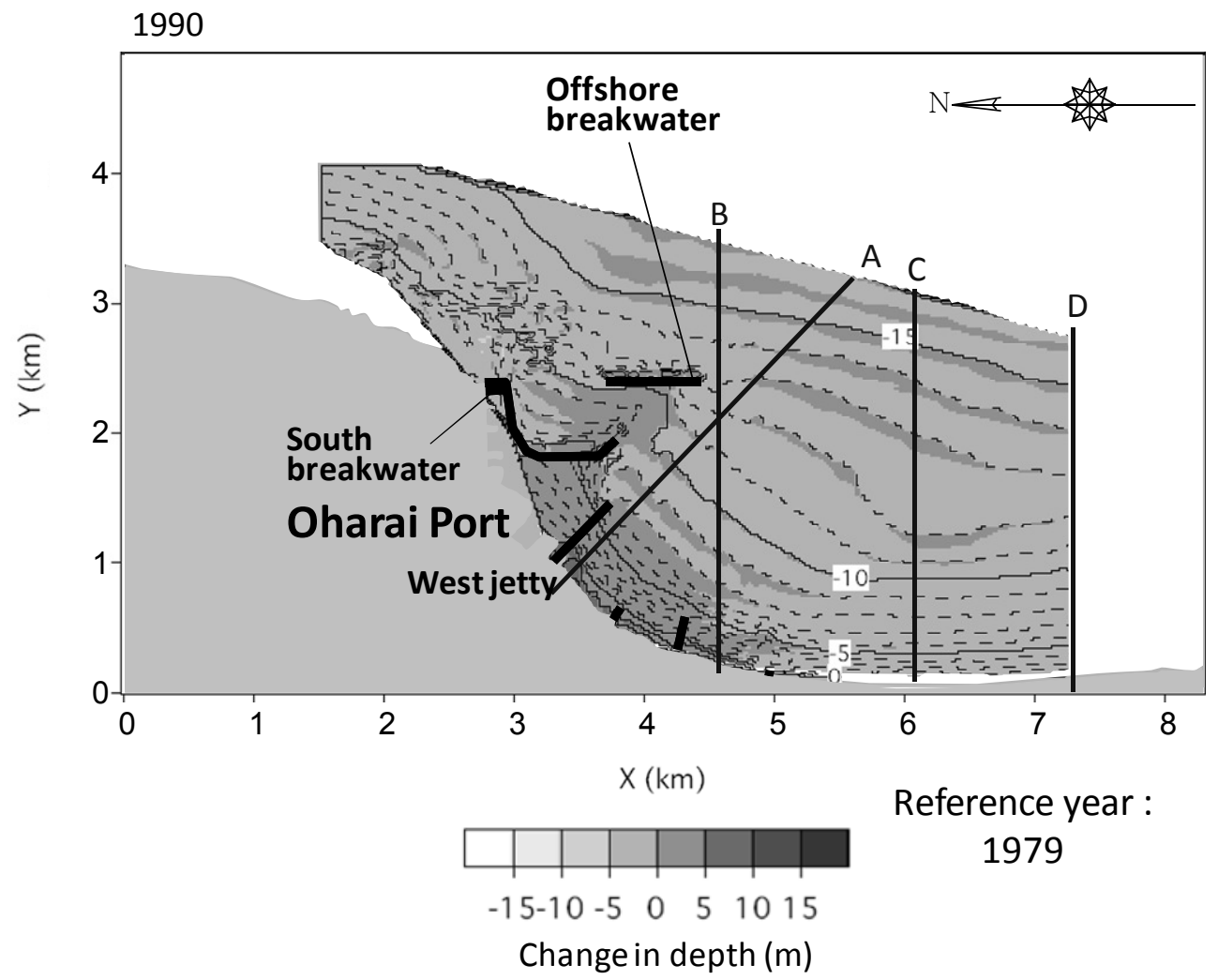

Figure 6. Bathymetric changes between 1979 and 1990 and alignment of transects. 


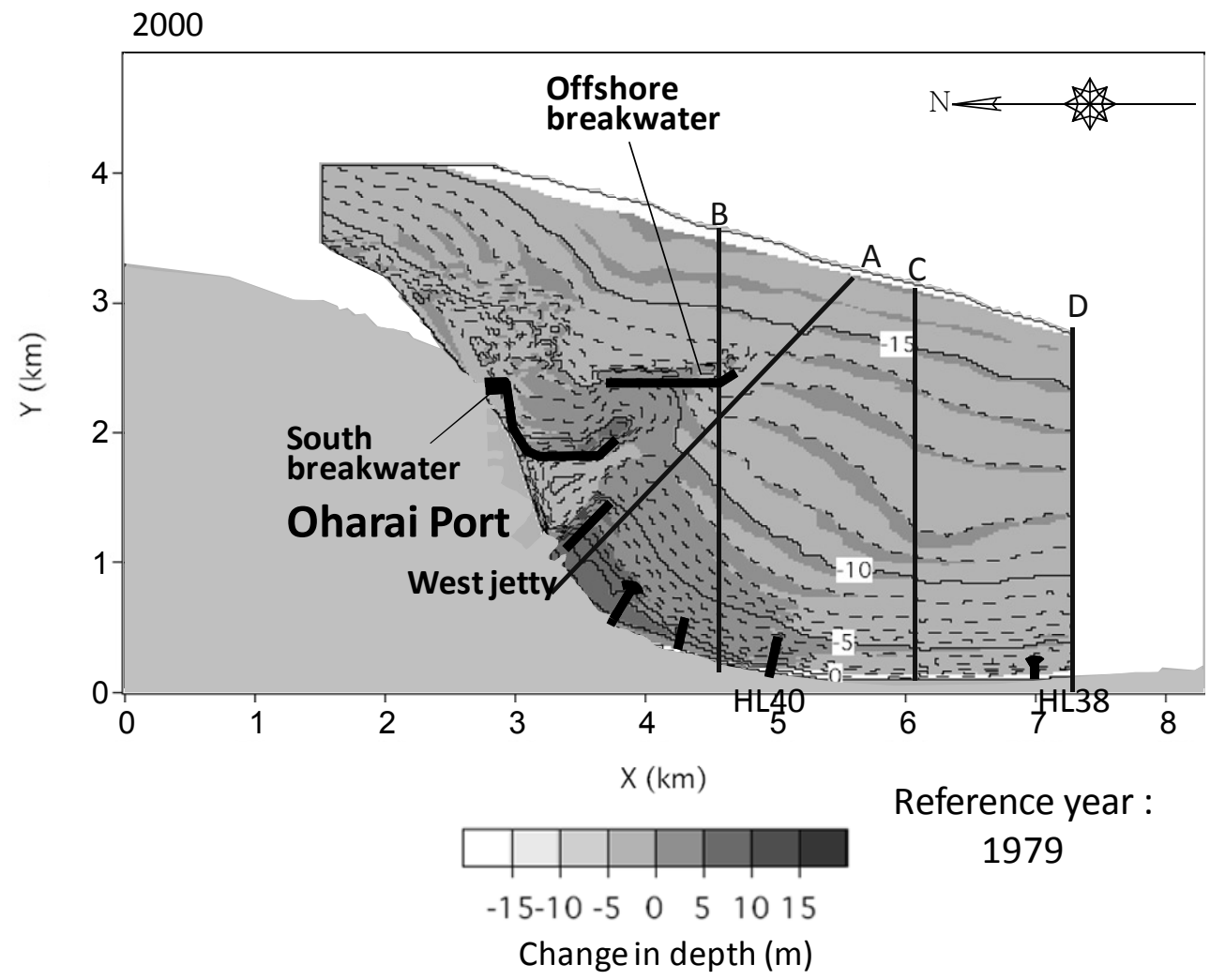

Figure 7. Bathymetric changes between 1979 and 2000 and alignment of transects.

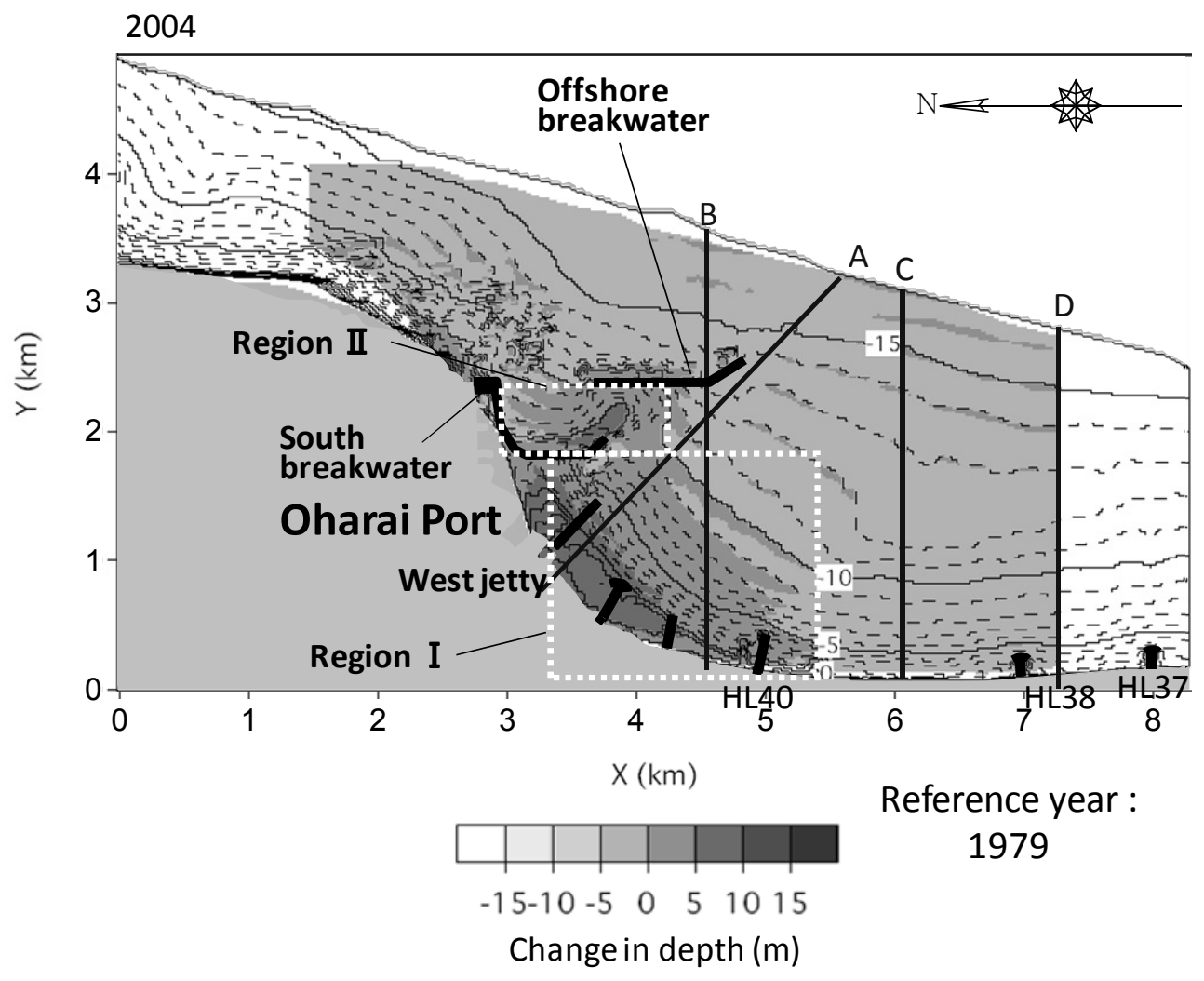

Figure 8. Bathymetric changes between 1979 and 2004 and alignment of transects. 


\section{TOPOGRAPHIC CHANGES}

The bathymetry and bathymetric changes in 1980 with reference to 1979 are shown in Fig. 5. The offshore breakwater had not yet been constructed and only the south breakwater of Oharai Port had been extended by 1980. In the south part of Oharai Port, the contour lines extended southwestward from Oharai Port in the vicinity of the port, as typically shown by the shape of the 10 -m-depth contour, and then they extended southward parallel with the coastline. In addition, there were submerged natural reefs over an extensive area east of Oharai Port.

By 1990, the offshore breakwater had been extended to a length of $800 \mathrm{~m}$, as shown in Fig. 6, and marked sand deposition had occurred in the area south of the west jetty due to the wave-sheltering effect of the extended offshore breakwater, whereas beach erosion was severe on the southern coast outside the wave-shelter zone. Note that sand deposition also occurred in the zone between the offshore and south breakwaters. This sand deposition zone is located on the east side of the south breakwater and north of the navigation channel to Oharai Port with $10 \mathrm{~m}$ depth, and therefore, it is difficult for sand to be transported by northward longshore sand transport while crossing this deep navigation channel. Thus, the deposited sand in this area is considered to be transported by southward longshore sand transport from the northern coast.

By 2000, the offshore breakwater including the oblique part at the tip had been further extended, as shown in Fig. 7. As a result, further sand deposition occurred immediately south of the west jetty. At the same time, a narrow sand deposition zone extended toward the offshore breakwater along the south breakwater, which extended southeastward. Taking the pattern of sand deposition into account, it is assumed that sand was transported southward along the south breakwater and deposited in the waveshelter zone of the offshore breakwater. In 2004, sand accumulation around the port was more dominant than that in 2000, as shown in Fig. 8. In particular, in the sand deposition zone between the south and offshore breakwaters, a slender sand accumulation zone markedly extended toward the lee of the offshore breakwater along the hooked south breakwater.

\section{SHORELINE CHANGES}

Figure 9 shows the shoreline changes in the sand deposition zone of Oharai Port. The shoreline has advanced over time since the construction of the breakwaters of Oharai Port and the maximum shoreline advance along the west jetty has reached $820 \mathrm{~m}$. It is clear that the shoreline has advanced in parallel in the wave-shelter zone and an artificial headland with $300 \mathrm{~m}$ length built as a measure against sand deposition is now completely buried with sand.

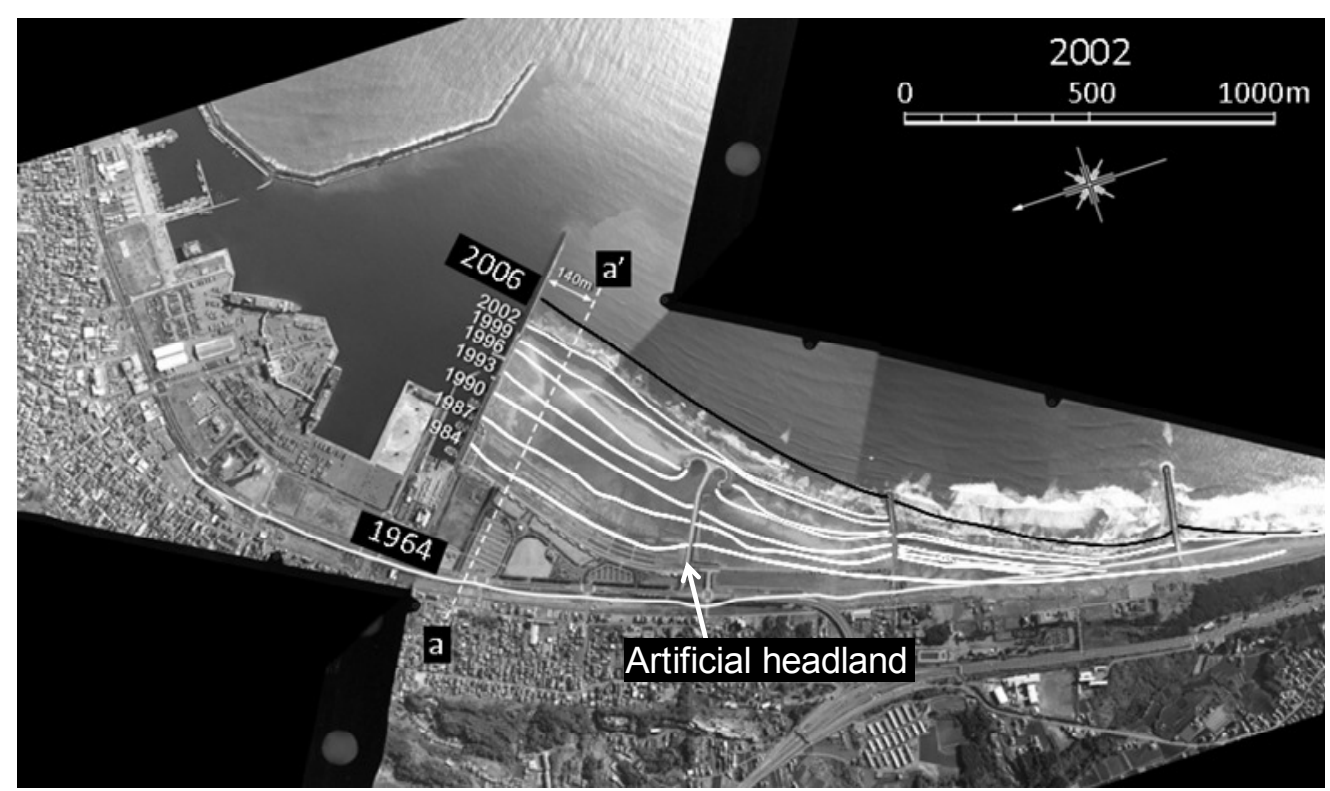

Figure 9. Shoreline changes south of Oharai Port. 
Figure 10 shows the temporal changes in shoreline position along transect a-a' shown in Fig. 9. The shoreline has gradually advanced over time, and the rate of shoreline advance was rapid immediately after the construction of the offshore breakwater in 1980. The shoreline advance exceeded $300 \mathrm{~m}$ during the first four years. Although the rate of shoreline advance has decreased with time, the shoreline was still advancing in 2002.

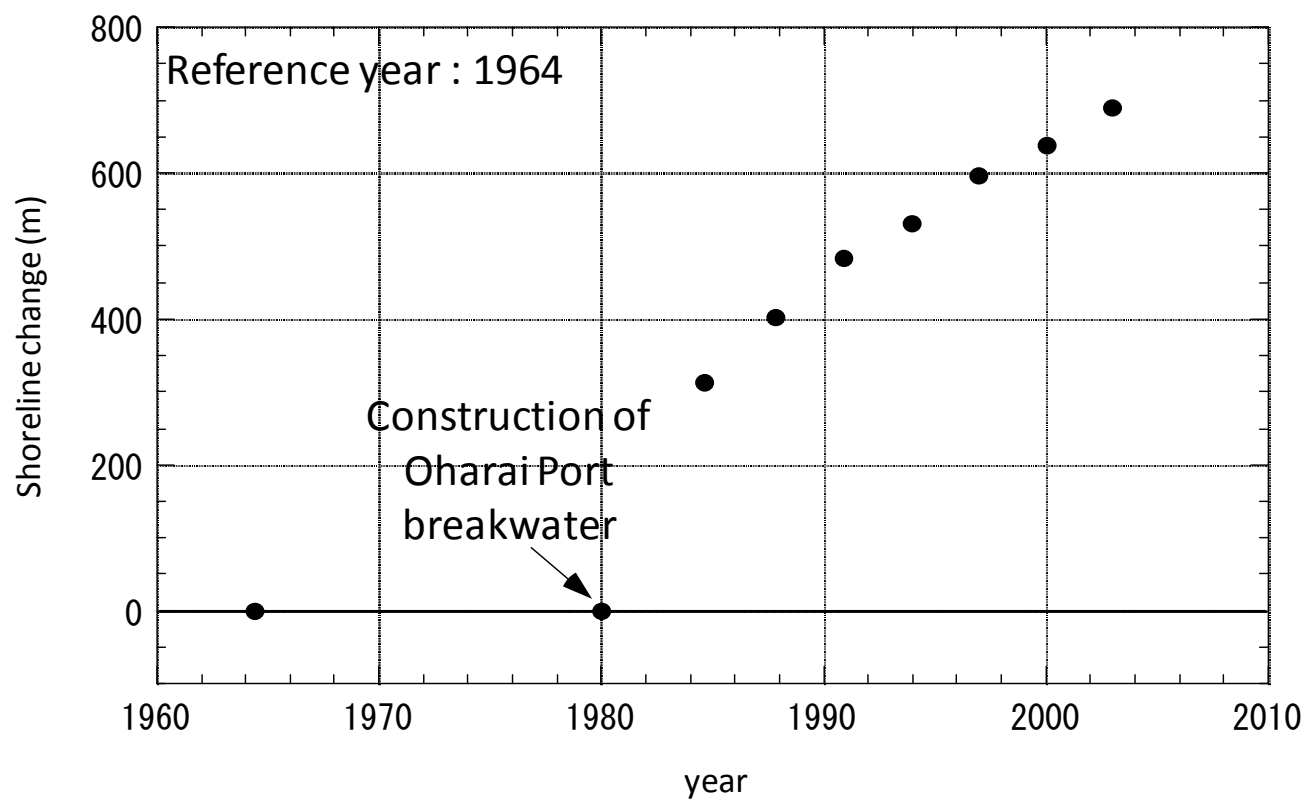

Figure 10. Temporal changes in shoreline position along a-a'.

When the shoreline change ( $\Delta \mathrm{y})$ along transect a-a' with reference to that in 1980 is calculated, $\Delta \mathrm{y}$ satisfies the following equation with a regression coefficient of 0.9998 :

$$
\Delta \mathrm{y}=147.3 \sqrt{\mathrm{t}} \text {. }
$$

Here $t$ is the number of years elapsed since 1980. In other words, the advance of the shoreline has been proportional to the square root of the elapsed time since 1980 .

\section{CHANGES IN LONGITUDINAL PROFILES AND GRAIN SIZE DISTRIBUTION}

The changes in longitudinal profiles along transects A, B, C and D between 1984 and 2004 are shown in Figs. 11(a)-11(d), respectively. Along transect A through the sand deposition zone, the shoreline advanced by $400 \mathrm{~m}$ between 1984 and 2004 owing to sand deposition in the offshore zone. Sand deposition occurred up to a depth of $9 \mathrm{~m}$, suggesting that the depth of closure of this coast is approximately $9 \mathrm{~m}$. Although a small amount of sand was deposited near $\mathrm{Y}=1,500 \mathrm{~m}$, this is considered to be due to the effect of local scouring around the tip of the offshore breakwater because of the proximity of this transect to its tip.

Along transect B, sand was deposited similarly to along transect A, and an upward concave profile developed with a gradual decrease in the longitudinal slope (Fig. 11(b)). An upward concave profile had formed by 1980 because transect B was located in the erosion zone associated with the wavesheltering effect of the south breakwater before the extension of the offshore breakwater. Then, the shoreline zone along this transect became part of the wave-shelter zone of the offshore breakwater, resulting in sand deposition. The depth of closure is also $9 \mathrm{~m}$ along transect $\mathrm{B}$.

Along transects $\mathrm{C}$ and $\mathrm{D}$ in the erosion zone, the shoreline retreated and the seawall became exposed to waves (Figs. 11(c) and 11(d)). The seabed was eroded up to $9 \mathrm{~m}$ depth along transect $C$, but a gentle slope extended in the zone deeper than $9 \mathrm{~m}$. The depth of closure along transect $\mathrm{D}$ is also about $9 \mathrm{~m}$. It is concluded that the depth of closure in the entire study area is equal to approximately $9 \mathrm{~m}$. 
(a) Transect A
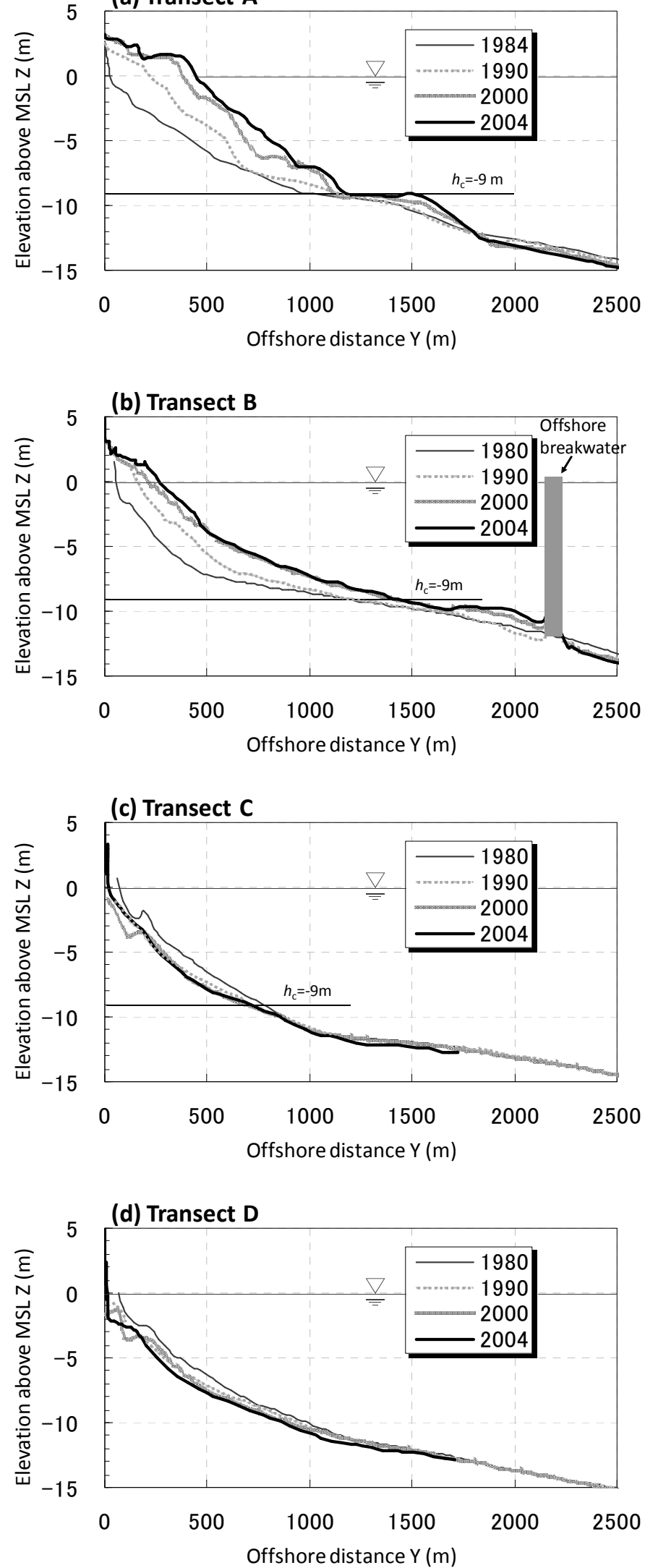

Figure 11. Changes in longitudinal profiles along transects A, B, C and D. 
Figures 12(a) and 12(b) show the depth distributions of the median diameter of seabed materials $\mathrm{d}_{50}$ along transects $\mathrm{B}$ and D. $\mathrm{d}_{50}$ near the shoreline of transect $\mathrm{B}$ in the deposition zone is $0.2-0.3 \mathrm{~mm}$, but it converges to approximately $0.1 \mathrm{~mm}$ with increasing depth. On the other hand, $\mathrm{d}_{50}$ near the shoreline of transect D in the erosion zone has increased over time and in 2000 reached $20 \mathrm{~mm}, 100$ times larger than the initial grain size, whereas the grain size in the offshore zone has remained constant at $0.1 \mathrm{~mm}$, similar to that along transect B. These results imply that fine sand was selectively transported away by the northward longshore sand transport in the vicinity of transect $\mathrm{D}$, resulting in the formation of a seabed covered with coarser material and the steepening of the beach slope. In contrast, fine sand selectively accumulated in the wave-shelter zone. Kumada et al. (2007) reported the results of predicting beach changes using the contour-line-change model, which considers changes in grain size, and the measured results demonstrate the effectiveness of such predictive models.

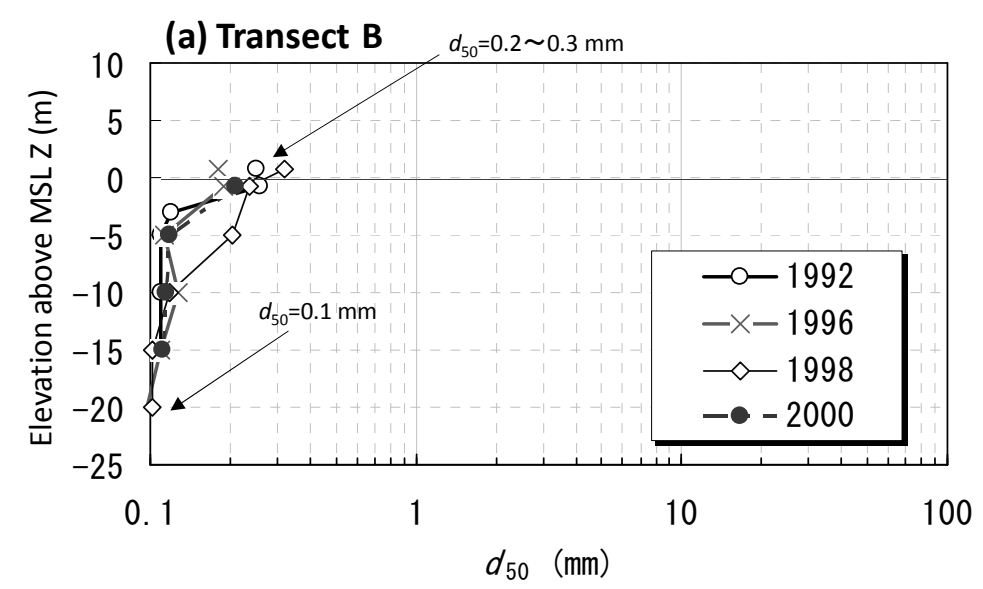

(b) Transect D

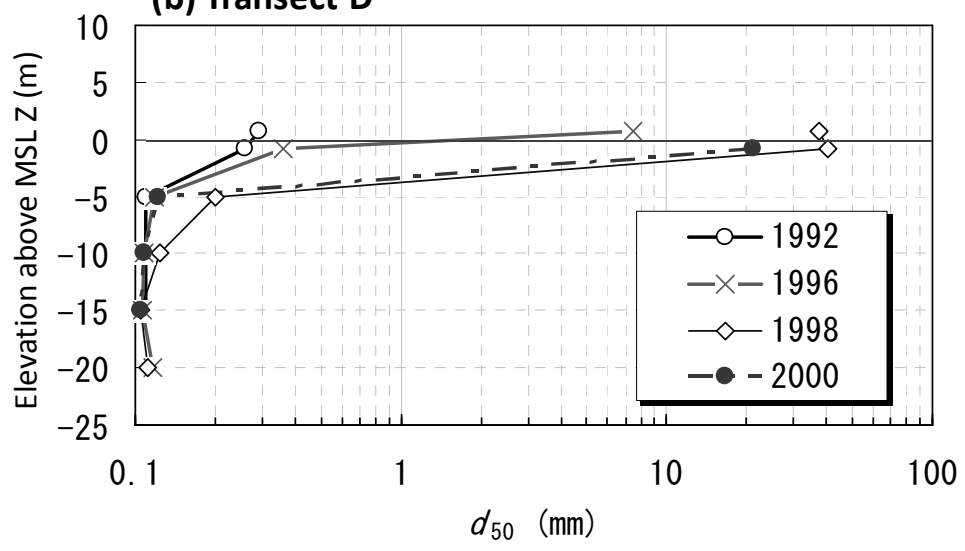

Figure 12. Depth distributions of median diameter along transects B and D.

\section{CHANGES IN ACCUMULATED SAND VOLUME}

In the vicinity of Oharai Port, marked sand deposition has occurred in the area south of the west jetty and between the south and offshore breakwaters. Taking this fact into account, regions I and II are set, as shown in Fig. 8, with each region surrounding a sand deposition zone, and the volumes of sand that have deposited in these regions since 1979 were investigated. The sand volume in region I, south of the west jetty, is shown in Fig. 13. The volume of sand has increased over time; a total volume of $7 \times$ $10^{6} \mathrm{~m}^{3}$ was deposited between 1979 and 2004, an average rate of $2.8 \times 10^{5} \mathrm{~m}^{3} / \mathrm{yr}$. This rate is approximately equal to that of $2.5 \times 10^{5} \mathrm{~m}^{3} / \mathrm{yr}$ estimated by Kumada et al. (2007) for the period between 1984 and 2005. The rate of accumulation has remained approximately constant; thus, beach erosion south of the port and accretion inside the wave-shelter zone of the port are expected to continue. This is because the offshore breakwater was gradually extended since 1979 . 


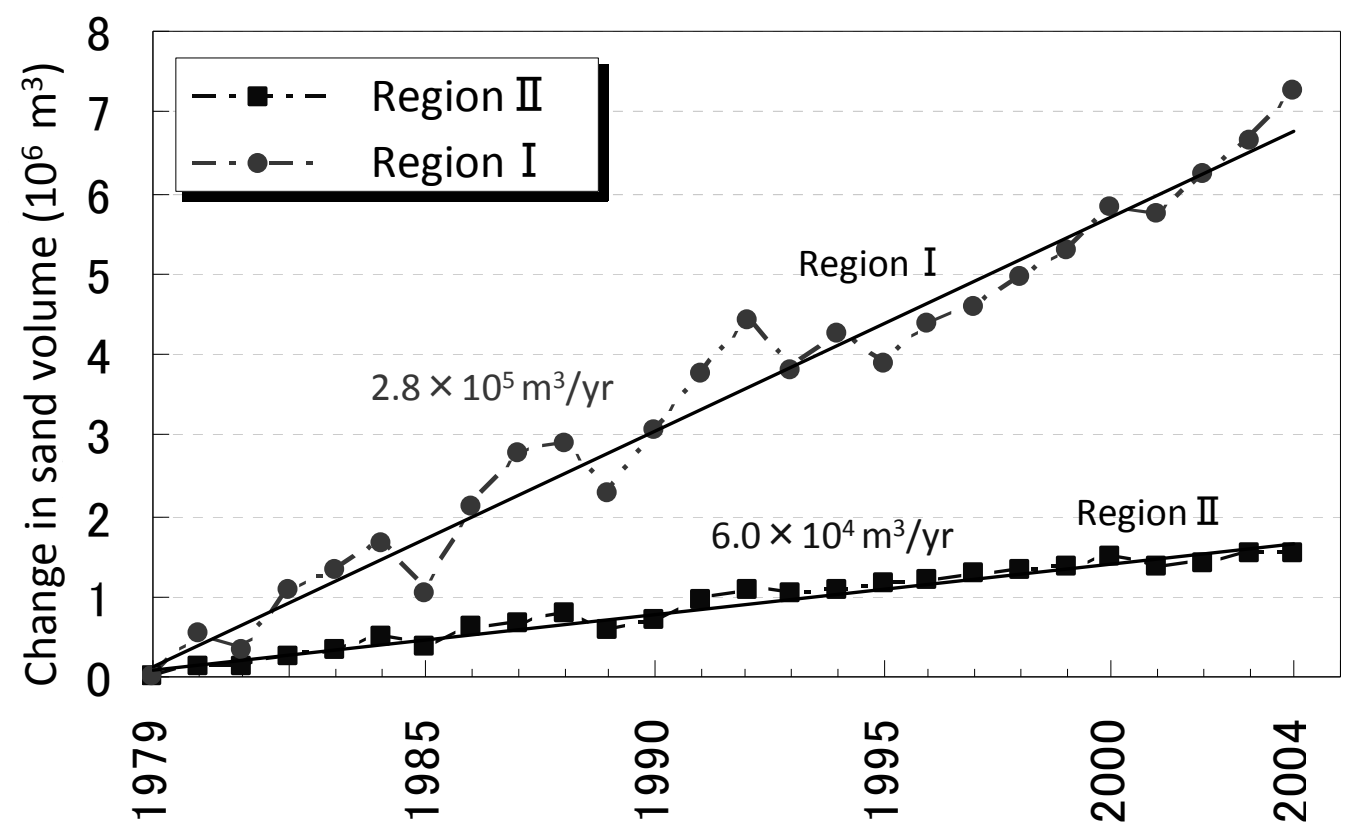

Figure 13. Changes in accumulated volume of sand in regions I and II.

Similarly the volume change in region II, between the south and offshore breakwaters, is also shown in Fig. 13. In this area, a total of $1.5 \times 10^{6} \mathrm{~m}^{3}$ of sand was deposited between 1979 and 2004, an average rate of $6.0 \times 10^{4} \mathrm{~m}^{3} / \mathrm{yr}$. It is difficult for sand to be transported by northward longshore sand transport while crossing the deep navigation channel with $10 \mathrm{~m}$ depth between the south breakwater and the west jetty. Furthermore, southward longshore sand transport prevails under the predominant wave direction from the east on the coast north of Oharai Port, and the Naka River flows into the Pacific Ocean $3 \mathrm{~km}$ north of the port, implying that the source of the sand deposited in region II is fluvial sand supplied from the river; thus, the sediment supply from the Naka River is $6.0 \times 10^{4} \mathrm{~m}^{3} / \mathrm{yr}$. Nagayama et al. (2008) estimated that the sediment supply from the Tone River, which flows into the Pacific Ocean at the south end of the Kashimanada coast, is approximately $1.0 \times 10^{5} \mathrm{~m}^{3} / \mathrm{yr}$ on the basis of bathymetric survey data. The ratio of sediment supply from the Naka River to that from the Tone River is 0.6.

According to the depth distribution of $\mathrm{d}_{50}$ along transect $\mathrm{B}$, as shown in Fig. 12(a), sand deposited in the zone deeper than $5 \mathrm{~m}$ is mainly composed of fine sand with a grain size of $0.12 \mathrm{~mm}$, and therefore, fine sand with approximately the same grain size is assumed to be deposited in the zone deeper than $5 \mathrm{~m}$ between the south and offshore breakwaters.

This sand deposition zone between the south and offshore breakwaters has gradually extended toward the navigation channel, and the siltation of the navigation channel is of concern. Taking into consideration the fact that sand deposited between the south and offshore breakwaters was supplied to the Kashimanada coast before the breakwaters were built, it is reasonable for the sand to be dredged and used as material for beach nourishment on the coast south of Oharai Port.

The works for maintaining the navigation channel in the wave-shelter zone of the port, where sand is excessively deposited, and the shore protection works outside the wave-shelter zone have been independently carried out in Japan by the different management offices, causing the difficulty in the comprehensive management of sand, such as sand bypassing and sand back passing (Uda, 2010). The beach changes around Oharai Port exactly fit the case. To remedy the problems, the works should be done by the relevant agencies with closer cooperation. 


\section{CONCLUSIONS}

1. In region $\mathrm{I}$, south of the west jetty of Oharai Port, $7.0 \times 10^{6} \mathrm{~m}^{3}$ of sand was deposited between 1979 and 2004 after the offshore breakwater was constructed. The average rate of accumulation was 2.8 $\times 10^{5} \mathrm{~m}^{3} / \mathrm{yr}$. This is attributable to the northward longshore sand transport induced by the formation of the wave-shelter zone associated with the extension of the offshore breakwater.

2. In region II, east of the south breakwater, a total of $1.5 \times 10^{6} \mathrm{~m}^{3}$ of sand was deposited between 1979 and 2004, an average rate of $6.0 \times 10^{4} \mathrm{~m}^{3} / \mathrm{yr}$, which is equal to the sand supply from the Naka River, one of the main sources of sand on the Kashimanada coast.

3. It was shown that fine sand is selectively deposited in the wave-shelter zone, leaving coarse material in the erosion zone. This shows that we must take into account the sorting effect of seabed materials in an extensive region and that the contour-line-change model, which considers changes in grain size (Kumada et al., 2007) should be applied to predict beach changes.

4. Sand deposited in region II of Oharai Port would have been transported to the Kashimanada coast but is now completely obstructed by the port breakwater. Sand bypassing to the coast south of the port is required to remedy the lack of sand on the south coast. Such works should be done by the relevant agencies with closer cooperation.

\section{REFERENCES}

Kumada, T., T. Uda and M. Serizawa. 2007. Quantitative evaluation of controlling effect of headland on longshore sand transport using model for predicting changes in contour lines and grain size, Coastal Sediments '07, ASCE, 2446-2459.

Mimura, N. and H. Kato. 1991. Topographic responses to the construction of large port structure on Oharai coast, Coastal Sediments '91, ASCE, 2292-2306.

Nagayama, H., T. Uda, T. Matsu-ura and T. Kumada. 2008. Prediction of bathymetric and grain size changes around port subject to active supply of sand from large river, Proc. $31^{\text {st }}$ ICCE, 2110-2122.

Uda, T. 2009. Beach erosion arising from anthropogenic factors, Proc. Coastal Dynamics 2009, Keynote 1, 1-17.

Uda, T. 2010. Japan's Beach Erosion - Reality and Future Measures, World Scientific, 418 pp. 